\title{
The cysteine protease ATG4B of Trichinella spiralis promotes larval invasion into the intestine of the host
}

\author{
Yalan Li', Baiyan Wang ${ }^{2}$, Yaxin Zhu², Zhihua Tian² ${ }^{2}$ Zhuo Yang ${ }^{2}$, Jiaqi Duan² and Zhongquan Wang ${ }^{1^{*}}$ (I)
}

\begin{abstract}
The cysteine proteases of parasites are vital contributors that induce parasite migration to and invasion of host tissue. In this study, we analysed the cysteine protease ATG4B of Trichinella spiralis (TsATG4B) isolated from the soluble proteins of Trichinella spiralis (T. spiralis) adult worms to ascertain its biochemical properties and functions during invasion into the intestine of the host. The $43 \mathrm{kDa}$ recombinant cysteine protease ATG4B protein (rTsATG4B) consists of a conserved peptidase_C54 domain and was expressed in Escherichia coli. Gelatine zymography showed that rTsATG4B could hydrolyse gelatine and that the hydrolytic activity was prevented by the cysteine protease inhibitor E-64 (pH 5.2). Immunofluorescence assays showed that TsATG4B is expressed at different stages and is localized at the cuticles and stichosomes of worms. Far-Western blotting and confocal microscopy revealed that rTsATG4B interacts with intestinal epithelial cells (IECs) and that it was subcellularly localized to the membrane and cytoplasm in IECs. Real-time quantitative PCR (qPCR) results indicated that the transcription level of the TsATG4B gene was the higher in 6-day-old adult worms ( 6 days AW) than in any other stage. An in vitro larval invasion assay verified that rTsATG4B promoted larval invasion and that invasion was inhibited when rTsATG4B was pre-incubated with E-64, whereas anti-rTsATG4B serum inhibited larval invasion in a dose-dependent manner. Collectively, these results suggested that the enzymatic activity of TsATG4B significantly influences the hydrolysis process, which is necessary for larval invasion of the host intestinal epithelium.
\end{abstract}

\section{Introduction}

Trichinellosis is a global food-borne parasitic zoonosis that remains an emerging disease that has been threatening public health and affecting economic growth [1-3]. Infection is initiated when uncooked or raw animal meat that has been contaminated with Trichinella spiralis (T. spiralis) is consumed [4,5]. After exposure to gastric juice in the gastrointestinal environment, T. spiralis muscle larvae (ML) are released from the capsules in the stomach. The worms grow by relying on intestinal contents, and they develop into intestinal infective larvae

*Correspondence: HNZZWang2019@163.com

1 Department of Pathogen Biology, School of Basic Medical Sciences, Zhengzhou University, Zhengzhou, China

Full list of author information is available at the end of the article
(IIL) in the intestine. Subsequently, IIL invade the epithelium of the small intestine, where they undergo 4 moults before developing into adult worms (AW), and they then mate and produce newborn larvae (NBL). NBL travel through the blood and lymph from the intestine to striated muscle, where they finally develop into L1 stage larvae in muscle cells [6, 7].

At the intestinal infection stage, the helminths establish an intramural niche with numerous epithelial cells and localize at the crypt-villus junction. When the nematodes can migrate in a sinusoidal pattern through the epithelium, they invade and inhabit the cytoplasm of new cells, leaving trails of dead cells behind [8]. T. spiralis larvae have no visible tools to promote their invasion, such as oral spikes, and the mechanisms by which T. spiralis larvae recognize, migrate to and invade the

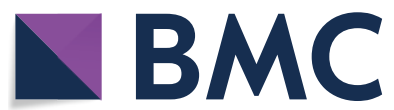

(c) The Author(s) 2020. This article is licensed under a Creative Commons Attribution 4.0 International License, which permits use, sharing, adaptation, distribution and reproduction in any medium or format, as long as you give appropriate credit to the original author(s) and the source, provide a link to the Creative Commons licence, and indicate if changes were made. The images or other third party material in this article are included in the article's Creative Commons licence, unless indicated otherwise in a credit line to the material. If material is not included in the article's Creative Commons licence and your intended use is not permitted by statutory regulation or exceeds the permitted use, you will need to obtain permission directly from the copyright holder. To view a copy of this licence, visit http://creativeco mmons.org/licenses/by/4.0/. The Creative Commons Public Domain Dedication waiver (http://creativecommons.org/publicdomain/ zero/1.0/) applies to the data made available in this article, unless otherwise stated in a credit line to the data. 
intestinal epithelium are not clear [9]. However, it has been reported that the mechanisms of larval invasion into the intestinal epithelium are not simply related to mechanical penetration but are related to the surface and oral secretory proteins of the worms $[10,11]$. To successfully breach the barrier of the intestinal epithelium, parasites must effectively degrade various host proteins but minimize tissue damage to reduce innate immune responses in order to swiftly and successfully infect the host [12]. Many parasitic helminths can utilize an array of host proteins, especially haemoglobin, as the principal source of amino acids. During this process, cysteine proteases are the key proteases of the helminths that degrade haemoglobin into amino acids [13]. Timms and Bueding [14] first described the proteases in schistosome extracts with an acidic optimum $\mathrm{pH}$. Currently, it is known that many proteases that play important roles in the degradation of haemoglobin into free amino acids, including cathepsin $\mathrm{D}$ (an aspartic protease of clan $\mathrm{AA}$ ) and cathepsins B1, C, L1/F, L2, and L3 (papain-like cysteine proteases of clan $\mathrm{CA}$, family $\mathrm{C} 1$ ) are secreted into the schistosome intestinal tract; thus, these proteases are highlighted as important drug targets $[15,16]$.

T. spiralis expresses different kinds of immunodominant antigens during all developmental stages [17]. These proteins have been verified to play critical roles in larval invasion and host immune system modulation, as well as in facilitating the establishment of parasitism and $T$. spiralis survival [18-22]. Moreover, research has shown that cysteine proteases play crucial roles in the invasion and migration of helminths throughout the host tissue $[23,24]$. Cysteine proteases from parasitic organisms can effectively degrade host tissue to promote the penetration and migration of helminths at various stages of parasite development; thus, they are vital contributors to these processes [12]. The cysteine protease ATG4B of $T$. spiralis belongs to the C54 peptidase family (Aut2 peptidase family, clan CA) [25]. TsATG4B protein, which is recognized in early $T$. spiralis-infected sera, and has also been suggested to be an immunodiagnostic antigen and a promising vaccine target, was isolated from the soluble protein of $T$. spiralis AW [23, 26]. Therefore, the purpose of this study was to ascertain the biochemical characteristics and functions of TsATG4B during the process of invasion of the host intestine.

\section{Materials and methods}

\section{Experimental animal housing conditions and parasite maintenance}

Experimental animals (BALB/c mice and Kunming mice) were purchased from the Experimental Animal Center of Henan Province, China. All experimental procedures were reviewed and approved by the Life Science Ethics
Committee of Henan Province (ethics approval number DWLL 201903062). The T. spiralis ISS 534 strain [27, 28] was initially obtained from domestic pigs in Henan Province, China, and serialized in Kunming female mice. Muscle larvae were obtained from the muscle of infected Kunming mice by artificial digestion [29]. AW were collected from the intestines of mice 3 and 6 days (d) after experimental infection. The 6 days AW were cultured in Roswell Park Memorial Institute (RPMI)-1640 medium for $24 \mathrm{~h}$, and NBL were harvested from the culture. Excretory-secretory (ES) products and soluble proteins of T. spiralis were prepared according to methods described in our previous study [30].

\section{Cell culture and cell lysate protein preparation}

Normal mouse intestinal epithelial cells (IECs) were previously isolated from BALB/c mouse intestines and maintained for the in vitro larval invasion assay [29]. Investigations revealed that the IECs were susceptible to larval invasion of $T$. spiralis, in contrast to $\mathrm{C} 2 \mathrm{C} 12$ cells from mouse striated muscle myoblasts, which were resistant to larval invasion. IECs were used in the in vitro larval invasion assay, and $\mathrm{C} 2 \mathrm{C} 12$ cells were used as a negative control. IECs and $\mathrm{C} 2 \mathrm{C} 12$ cells were cultured in $25 \mathrm{~cm}^{2}$ cell culture flasks (Corning, NY, USA) in Dulbecco's modified Eagle's medium (DMEM) (Solarbio, Beijing, China) supplemented with $5 \%$ foetal bovine serum (FBS) (Solarbio, China) and incubated in $5 \% \mathrm{CO}_{2}$ at $37{ }^{\circ} \mathrm{C}$. To maintain the cell cultures, the medium was renewed every 2 or 3 days, and cell monolayers were digested with $0.25 \%$ trypsin (Solarbio, China). Preparation of proteins from IEC and $\mathrm{C} 2 \mathrm{C} 12$ lysates was performed as described above [31].

\section{Bioinformatic analysis of TsATG4B}

According to the information provided by the National Center for Biotechnology Information (NCBI), the access number of the TsATG4B gene is XM_003371464.1. The access number for the TsATG4B protein is XP_003371512.1. Conserved domain analysis of TsATG4B was performed with the Conserved Domain database of NCBI. The open reading frames (ORFs) were identified in ORF Finder. The basic theoretical characterization of proteins, the molecular weight and the isoelectric point were analysed by bioinformatics software and web servers. SignalP4.1 Server was used to predict the signal peptide. The transmembrane domain was predicted by TMHMM Server v. 2.0. The TsATG4B protein domains were analysed with EMBL-EBI software. The B cell epitope was analysed by an online server. The phylogenetic tree of TsATG4B and homologous sequences was constructed by MEGA 7.0, and the phylogeny was constructed with the maximum parsimony method. 


\section{Cloning, expression, purification and refolding of recombinant TsATG4B}

To analyse the biochemical properties of TsATG4B, the full length TsATG4B gene (XM_003371464), which is $1245 \mathrm{bp}$ long, was initially synthesized, and the recombinant protein was expressed in Escherichia coli. PCR was performed to amplify the region comprising amino acid residues 18-414 with the following primers: $5^{\prime}$-ACC ATCACCATCACGGATCCCGATTGGAACTGCTCG ACGA-3' (the BamHI restriction site is underlined) and 5'-AAGCTCAGC TAATTAAGC TTTCATTCAAAA CCAACTTCAGATAT-3' (the HindIII restriction site is underlined). The thermal cycling procedure was as follows: predenaturation at $94{ }^{\circ} \mathrm{C}$ for $3 \mathrm{~min} ; 30$ cycles at $94{ }^{\circ} \mathrm{C}$ for $30 \mathrm{~s}, 60^{\circ} \mathrm{C}$ for $30 \mathrm{~s}$, and $72{ }^{\circ} \mathrm{C}$ for $90 \mathrm{~s}$; and final extension at $72{ }^{\circ} \mathrm{C}$ for $5 \mathrm{~min}$. The PCR product was subcloned into a $\mathrm{pQE}-80 \mathrm{~L}$ expression vector containing a His tag at the C-terminus (Novagen, La Jolla, USA) following the protocol of the ClonExpress II single-pass clone kit (Vazyme, Nanjing, China), and the recombinant plasmid pQE-80L/TsATG4B was then transformed into Escherichia coli BL21 (Novagen, La Jolla, USA) via induction with $0.5 \mathrm{mM}$ isopropyl-1-thio- $\beta$-D-galactopyranoside (IPTG) (Sangon Biotech Co., Shanghai, China) for $4 \mathrm{~h}$ at $37^{\circ} \mathrm{C}$ for protein expression.

To purify rTsATG4B, cells were harvested and lysed by sonication in a $200 \mathrm{~W}$ sonicator for $4 \mathrm{~s}$ and were then placed in ice water for a total of 200 cycles at $2 \mathrm{~s}$ per cycle. Then, rTsATG4B was centrifuged at $12000 \mathrm{~g}$ and $4{ }^{\circ} \mathrm{C}$ for $30 \mathrm{~min}$. rTsATG4B was mostly aggregated in inclusion bodies and was analysed by SDS-PAGE with a $10 \%$ acrylamide separating gel [13]. Then, the supernatant was discarded, and the inclusion body pellets were collected and resuspended in $20 \mathrm{~mL}$ of ice-cold inclusion body buffer solution containing $50 \mathrm{mM}$ Tris- $\mathrm{HCl}, 8 \mathrm{M}$ urea, $1 \mathrm{mM}$ ethylenediaminetetraacetic acid (EDTA), and $100 \mathrm{mM} \mathrm{NaCl}(\mathrm{pH} \mathrm{8.0)}$ to dissolve inclusion bodies [33]. The denatured protein was purified by metal affinity chromatography with Ni-NTA-Sefinose resin (Sangon Biotech Co., China) under denaturing conditions, according to the manufacturer's instructions [33]. SDS-PAGE separates proteins according to their molecular weight based on their differential rates of migration through a sieving matrix (gel) under the influence of an applied electrical field. Therefore, the expression and purification of rTsATG4B protein were confirmed by SDS-PAGE, and a single band with a molecular weight of $43 \mathrm{kDa}$ was observed on the SDS-PAGE gel (Figure 2A).

Via the "one-step-denaturing and refolding method" [32], purified rTsATG4B dissolved in inclusion body solubilization buffer was first placed in a dialysis bag (8000-14 $000 \mathrm{kDa}$, Solarbio, China), and the dialysis process was carried out with PBS medium for $4 \mathrm{~h}$. The PBS dialysis medium was kept cold to generate a clean and completely folded protein. Subsequently, the refolded protein was concentrated by ultrafiltration at $5000 \mathrm{~g}$ for 30 min (Millipore, Billerica, USA). After a second analysis by SDS-PAGE, the molecular weight of the heated refolded rTsATG4B was $43 \mathrm{kDa}$, which corresponded to the theoretical molecular weight calculated for the amino acid sequence.

\section{Production of infection sera and the anti-TsATG4B polyclonal antibody and identification of TsATG4B by Western blot analysis}

Infection serum was obtained from $\mathrm{BALB} / \mathrm{c}$ mice that were orally administered $300 \mathrm{~T}$. spiralis for $3,6,10,14$, 17, 20, 23, 26, 30, 36 and 42 days. Purified TsATG4B protein $(20 \mu \mathrm{g})$ was injected subcutaneously into one BALB/c mouse as a formulation with complete Freund's adjuvant (FA, Sigma, St. Louis, USA) according to the instructions. Two more injections of the same dose of rTsATG4B protein mixed with incomplete FA (Sigma, USA) were administered to mice over a 2-week period. Fourteen days after the last immunization, immune sera were collected, and the antibody titres were determined by ELISA [33].

Soluble proteins of ML, IIL, 3 days AW, $6 \mathrm{~d}$ AW, and NBL and ES proteins of ML were separated on 10\% polyacrylamide SDS-PAGE gels. After electrophoresis, the proteins were transferred to nitrocellulose membranes (Millipore, USA). Membranes were blocked with $5 \%$ nonfat dry milk, incubated with TsATG4B immune serum, T. spiralis-infected mouse serum or pre-immune mouse serum at $1: 100$ dilutions overnight at $4{ }^{\circ} \mathrm{C}$; washed with PBST three times for $10 \mathrm{~min}$ each, incubated with a horseradish peroxidase (HRP)-conjugated goat antimouse antibody (Sangon Biotech Co., China) at a 1:5000 dilution at $37^{\circ} \mathrm{C}$ for $1 \mathrm{~h}$, and washed 3 more times with PBST for 10 min each. Detection of protein bands was performed with 3,3'-diaminobenzidine tetrahydrochloride (DAB, Sigma, USA) in the dark. Images were acquired with an Image Scanner III (GE Healthcare, Chicago, USA) [31].

\section{Detection of refolded rTsATG4B activity by zymography}

For gelatine zymography, 10\% SDS-PAGE gels copolymerized with $1 \mathrm{mg} / \mathrm{mL}$ gelatine (Sigma) were used. To test the effect of the E-64 inhibitor, refolded rTsATG4B protein samples were incubated with E-64 $(10 \mathrm{mM})$ at a ratio of $1: 1(\mathrm{v} / \mathrm{v})$ at $37^{\circ} \mathrm{C}$ for $30 \mathrm{~min}$. Then, $25 \mu \mathrm{L}$ of each supernatant sample was loaded into each well under nonreducing (native) conditions, and samples were separated at $120 \mathrm{~V}$ for $2 \mathrm{~h}$. After electrophoresis, gels were transferred to clean containers and washed two times for 60 min each with $100 \mathrm{~mL}$ of $2.5 \%$ (v/v) Triton X-100 by 
gently shaking on a rotary stirrer at room temperature, and then the washes were repeated with distilled water three times. After incubating in acetate buffer $(\mathrm{pH} 5.2)$ with $1 \mathrm{mM}$ dithiothreitol for $36 \mathrm{~h}$ at $37{ }^{\circ} \mathrm{C}$, gels were washed three times with distilled water to remove the activation buffer. Next, gels were stained with Coomassie blue solution (Sangon Biotech Co., China) under constant stirring for $2 \mathrm{~h}$. Finally, gels were placed in a bleaching solution with $7 \%$ acetic acid and 5\% methanol for $1 \mathrm{~h}$ to identify the bands with proteolytic activity [34-36]. The same samples were separated by $10 \%$ SDSPAGE under non-reducing (native) conditions, and proteins were then transferred to nitrocellulose membranes. Western blot detection was performed as mentioned above. Images were acquired with an Image Scanner III (GE Healthcare, USA).

\section{Real-time quantitative PCR (qPCR) analysis of TsATG4B gene transcription}

Total RNA from ML, IIL, 3 days AW, 6 days AW and NBL was extracted by TRIZOL reagent (Invitrogen ${ }^{\mathrm{TM}}$, Carlsbad, USA) and reverse transcribed with a Prime Script RT Reagent Kit with gDNA Eraser (Takara, Tokyo, Japan). The T. spiralis $18 S$ rRNA gene (GenBank accession number U60231) was used as the internal control with the primers $5^{\prime}$-CAACCTTCGATGGTAGCCTAT GCG-3' and 5'-CCTGCTGCCTTCCTTGGATGTG-3', and the predicted length was $117 \mathrm{bp}$ [33]. The primers 5'-TCCCCATTATAGTCAACCTGCT-3' and 5'-TGG ATATTTACAATGAAAACTGTGAAG- $3^{\prime}$ were designed to be specific for the TSATG4B gene, with the predicted length of the product being $76 \mathrm{bp}$. qPCR was performed in a $20 \mu \mathrm{L}$ reaction mixture containing SYBR Premix (Takara, Japan), cDNA, primers, and ROX Reference Dye II in an ABI 7300 real-time PCR system (Applied Biosystems, Foster City, USA). The different transcription levels were calculated with the formula $2^{-\Delta \Delta \mathrm{Ct}}$ [37]. The experiment was repeated three times $(n=3)$.

\section{Expression and immunolocalization of TsATG4B at various stages by an immunofluorescence test}

An immunofluorescence test (IFT) was used to determine the localization of the native TsATG4B protein at various T. spiralis developmental stages, and paraffin sections were also tested. Live T. spiralis worms at different developmental stages (ML, IIL, AW and NBL) were fixed with paraformaldehyde for $30 \mathrm{~min}$ after being washed three times, fixed with cool acetone for $20 \mathrm{~min}$, and subsequently washed three more times. The worms and paraffin sections were blocked with $5 \%$ normal goat serum and incubated in a humidified chamber at $37^{\circ} \mathrm{C}$ for $1 \mathrm{~h}$. The goat serum was then discarded, and the slides with worms were incubated with pre-immune mouse serum diluted 20-fold (negative control), T. spiralis infection serum (positive control) and the anti-TsATG4B polyclonal antibody at $37^{\circ} \mathrm{C}$ for $1 \mathrm{~h}$. After three washes with PBS, the slides and worms were incubated with FITClabelled goat anti-mouse IgG (Sigma, USA) at a 1:100 dilution at $37{ }^{\circ} \mathrm{C}$ for $45 \mathrm{~min}$. After being washed, the slides and worms were observed under a fluorescence microscope (Olympus, Tokyo, Japan), and images were acquired.

\section{Immunofluorescence assay and Far-Western blot}

For the IEC and $\mathrm{C} 2 \mathrm{C} 12$ cell immunofluorescence assays, IECs and $\mathrm{C} 2 \mathrm{C} 12$ cells were grown in DMEM containing 10\% FBS (Solarbio, China). IEC and C2C12 cells were seeded after digestion with trypsin $(0.25 \%$, Solarbio, China) on glass coverslips coated with poly-L-lysine (Solarbio, China). Cells were grown in a 6-well cell culture plate for $36 \mathrm{~h}$ to a confluence of approximately $90 \%$. The culture medium was discarded, and the glass coverslips were washed three times with PBS, fixed in acetone for $10 \mathrm{~min}$, blocked with $5 \%$ goat serum at $37^{\circ} \mathrm{C}$ for $2 \mathrm{~h}$, and finally incubated with $20 \mu \mathrm{g} / \mathrm{mL}$ TsATG4B (at $37{ }^{\circ} \mathrm{C}$ for $2 \mathrm{~h}$, with $\mathrm{PBS}$ as the negative control). After three washes with PBS, cells were probed with the first and second antibodies, following the previously mentioned IFT protocols. Images were acquired with a laser scanning microscope (Olympus FV1200, Olympus, Tokyo, Japan).

The protein-protein interaction between TsATG4B and IECs was analysed by Far-Western blotting. After the proteins in the samples of IEC and C2C12 cell lysates were separated by SDS-PAGE with $10 \%$ polyacrylamide gels, the proteins were transferred to $\mathrm{NC}$ membranes. The NC membranes were incubated with $20 \mu \mathrm{g} / \mathrm{mL}$ rTsATG4B for $1 \mathrm{~h}$ at $37^{\circ} \mathrm{C}$ and then analysed by Western blotting. After the membranes were washed, the protein bands were stained with DAB (Sigma, USA) in the dark, and the reaction was terminated with distilled water. Images were acquired with an Image Scanner III (GE Healthcare, USA).

\section{In vitro invasion assay}

To evaluate the effects of rTsATG4B and anti-rTsATG4B serum on larval invasion of the intestinal epithelium, a $T$. spiralis invasion test was performed in vitro. IECs were cultured to full confluence in 6-well plates. ML were stimulated to develop into IIL by treatment with $5 \%$ porcine bile at $37{ }^{\circ} \mathrm{C}$ for $2 \mathrm{~h}$ [8]. Two groups of TsATG4B with different concentrations ranging from 2.5 to $15 \mu \mathrm{g} /$ $\mathrm{mL}$ were prepared, and one group was pre-incubated with E-64 $(10 \mu \mathrm{M}, 1: 1)$ at $37^{\circ} \mathrm{C}$ for $30 \mathrm{~min}$. Subsequently, 1:50 to $1: 1600$ dilutions of serum (anti-TsATG4B serum, T. spiralis-infected mouse serum and pre-immune mouse serum) were prepared. Then, the samples of each 
treatment group were added to $1.75 \%$ agarose semi-solid medium containing $100 \mathrm{IIL}$ and gently mixed at $38{ }^{\circ} \mathrm{C}$ to $40{ }^{\circ} \mathrm{C}$. The mixed medium was overlaid on the monolayer of IECs in each well and formed a semi-solid medium. After incubation in $5 \% \mathrm{CO}_{2}$ at $37^{\circ} \mathrm{C}$ for $2 \mathrm{~h}$, larval invasion of IECs in each treatment group was observed. Larvae that invaded or migrated in the IEC monolayer showed trails, leaving dead cells behind and destroying the IEC monolayer. Larvae suspended in the medium or on the cell monolayer surface, which did not stretch or damage the cell monolayer, were defined as uninvaded larvae. Experiments were conducted in triplicate [31,35].

\section{Statistical analysis}

The data were analysed statistically with IBM SPSS Statistics 25.0 for Windows (IBM Corporation, NY, USA). The relative expression data of the TsATG4B gene in ML, IIL, 3 days AW, 6 days AW and NBL are displayed as the mean $\pm \mathrm{SD}$ values, and one-way ANOVA was used to compare the differences among the groups. The different percentages of invaded larvae in the IEC monolayers with different concentrations $(0-15 \mu \mathrm{g} / \mathrm{mL})$ of TsATG4B and different serum dilutions were analysed using a Chi square test. Statistical significance was defined as $P<0.05$.

\section{Results}

\section{Bioinformatic analysis of TsATG4B and phylogenetic analysis of TsATG4B}

The complete CDS of TsATG4B (XM_003371464.1) contains an open reading frame of 1245 bp encoding a protein of 414 aa that contains a conserved peptidase C54 domain (aa 79-404) and has a calculated molecular weight of $46.94 \mathrm{kDa}$ and an isoelectric point of 5.79. Signal P 4.1 Server prediction showed that there was no signal peptide and that the protein was a non-secretory protein. It was predicted that aa 33-43, aa 55-62, aa $176-182$, aa $236-244$, aa $246-255$, aa $261-268$, aa 271-277, and aa 286-293 were B-cell epitopes. Phylogenetic analysis of the peptidase_C54 domain of different kinds of organisms favoured the monophyletic group of six species of Trichinella (Trichinella nelson, Trichinella patagoniensis, Trichinella native, Trichinella murrelli, Trichinella britovi, and Trichinella sp. T9) (Figure 1).

\section{Purification and gelatinolytic activity of rTsATG4B}

To analyse the biochemical and immunogenic properties of TsATG4B, the amplified fragment (1194 bp, containing the conserved peptidase_C54 domain) was cloned into the $\mathrm{pQE}-80 \mathrm{~L}$ expression vector with a seamless clone kit. The TsATG4B protein fused with a His-tag was expressed in $E$. coli cells and purified with $\mathrm{Ni}$-affinity chromatography. After analysis by SDS-PAGE, a single band was observed on the SDS-PAGE gel at a molecular weight of approximately $43 \mathrm{kDa}$, consistent with the calculated molecular weight (Figure 2A, lane 3). In the 1-D gelatine zymogram of purified rTsATG4B, the clear band revealed gelatinolytic activity (Figure 2B, lane 1) and was eliminated by treatment with E-64 (Figure 2B, lane 2), a cysteine protease inhibitor. Furthermore, the band of refolded rTsATG4B was at the same position and

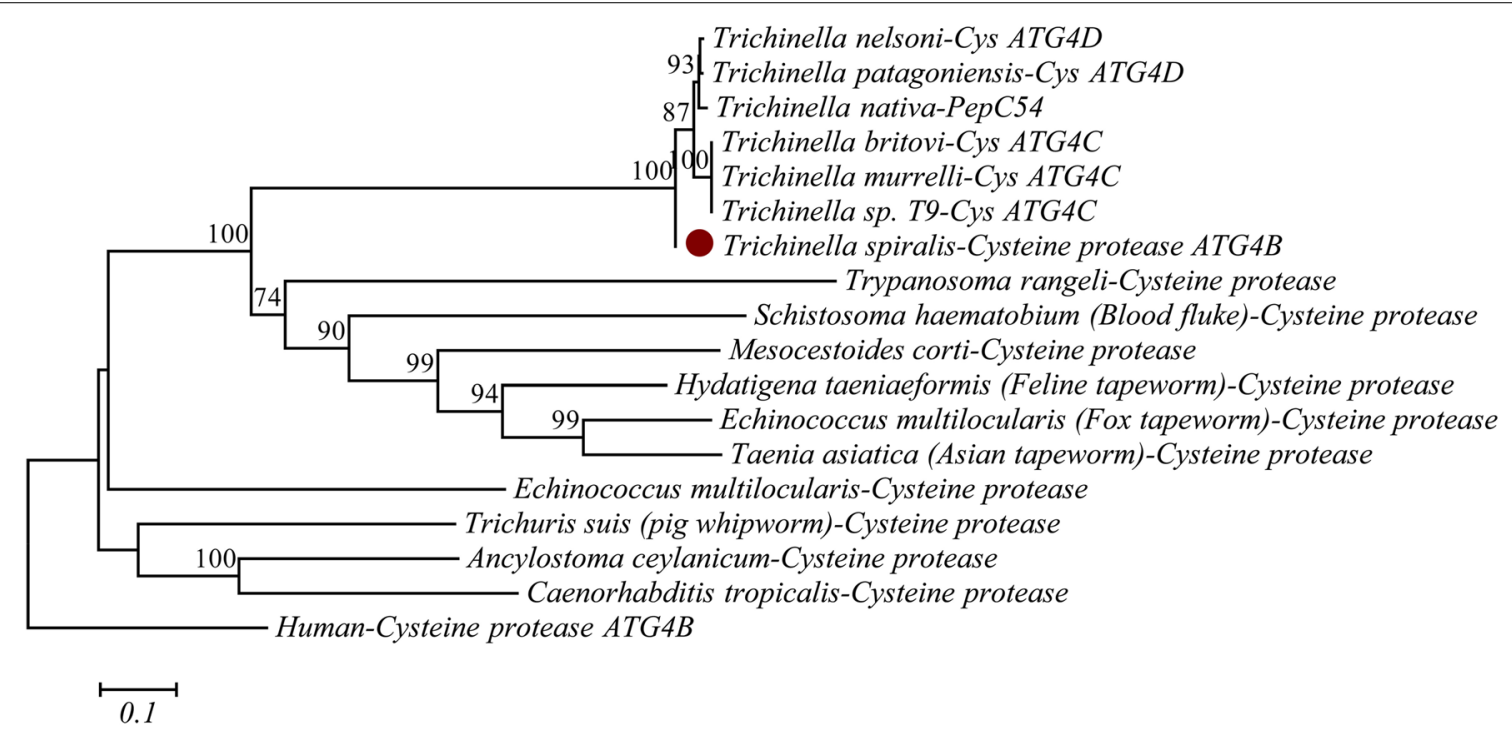

Figure 1 Analysis of the phylogenetic tree of TsATG4B. Phylogenetic relationship of the peptidase_C54 domain of nematodes and humans using the maximum parsimony method and drawn by MEGA. Bootstrap values of less than 70 are hidden in the branches. The sequence denoted by a solid circle is that of the TsATG4B protein expressed in this study. 


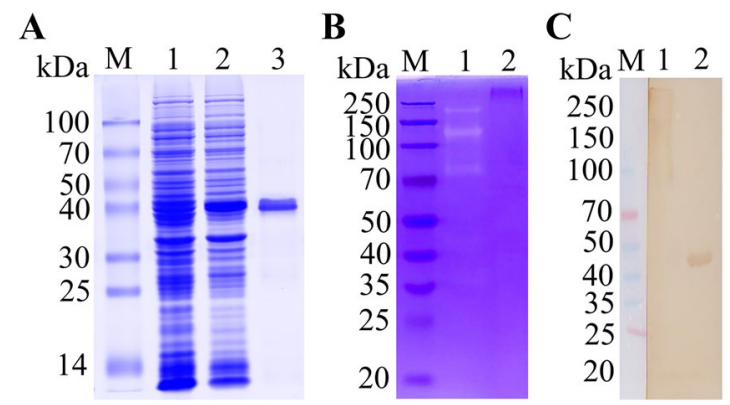

Figure 2 Expression, purification and gelatinolytic activity of rTsATG4B. A Expression and purification of rTsATG4B. Lane M: standard marker; lanes 1/2, lysate of BL21 bacteria harbouring pQE-80L/TsATG4B without/with IPTG induction; lane 3: purified recombinant TsATG4B; B Proteolytic activity of refolded TsATG4B as detected by gelatine zymography. Lane M: protein molecular weight marker; lane 1: transparent strips due to the proteolytic activity of refolded TSATG $4 B$ in acrylamide-gelatine gels; lane 2: refolded rTsATG4B pre-incubated with the protease inhibitor E-64; C Identification of refolded rTsATG4B by Western blotting. Lane M: protein molecular weight marker; lane 1: refolded rTsATG4B recognized by anti-TsATG $4 B$ serum (1:100 dilution); lane 2: denatured rTsATG4B recognized by anti-TsATG4B serum (1:100 dilution).

was recognized by anti-TsATG4B serum (1:100 dilution), as indicated by Western blot analysis (Figure 2C). This result showed that the hydrolysed bands of gelatine were generated due to the hydrolytic activity of rTsATG4B.

\section{Identification of TsATG4B}

The qPCR results indicated that the TsATG4B gene was transcribed during different stages (NBL, ML, IIL, 3 days AW and 6 days AW) (Figure 3A). The transcription level of the TsATG4B gene in 6 days AW was significantly higher than that in ML, IIL, 3 days AW and NBL (F $(4)=98.144, P<0.01)$. The amplicons of the TsATG4B gene and T. spiralis $18 S r R N A$ gene were displayed as $76 \mathrm{bp}$ and $117 \mathrm{bp}$, respectively, by $5 \%$ agarose gel electrophoresis (Additional file 1).

The Western blot results showed that the rTsATG4B protein was recognized by anti-rTsATG4B serum and serum from mice infected for $20-30$ days. The antiTsATG4B polyclonal antibody recognized the native TsATG4B protein among somatic proteins from NBL, ML, IIL, 3 days AW and 6 days AW and ES products from ML, as indicated by Western blot analysis, illustrating that the TsATG4B protein was a constituent of these proteins (Figures $3 \mathrm{C}, \mathrm{D}$ ).

The results of IFT revealed intense immunostaining in the cuticles of intact worms and that TsATG4B was expressed at different $T$. spiralis stages (Figure 4). Bright immunostaining was observed on the cuticles, surfaces and stichosomes of the paraffin sections of the worms incubated with immune serum and infection serum

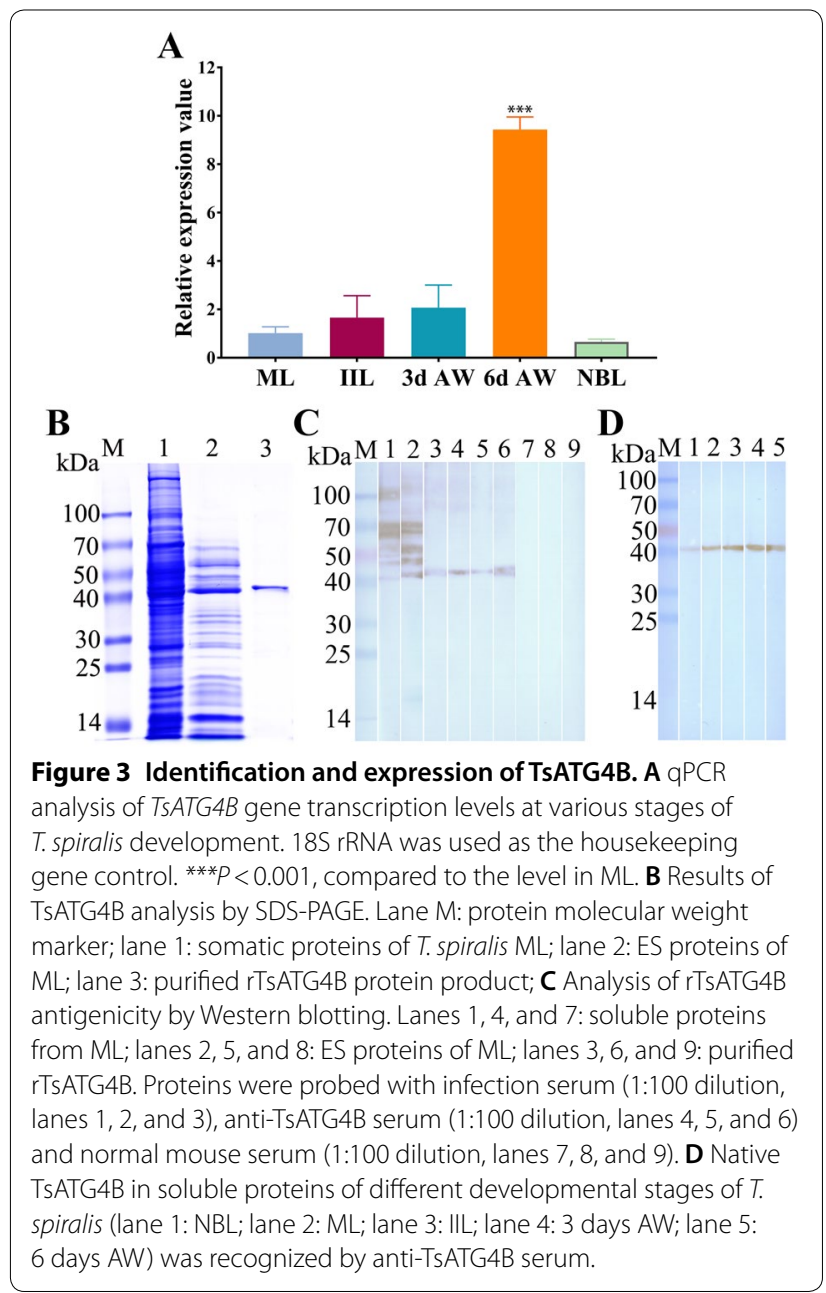

(Figure 4), but no immunostaining was observed in the worms incubated with pre-immune serum or PBS (Additional file 2).

\section{Interaction of TsATG4B with IECs by immunofluorescence assay and Far-Western blot analysis}

Fluorescence staining was observed on the surface of IECs incubated with rTsATG4B and probed with antirTsATG4B serum and infection serum but was not detected on IECs probed with normal serum. Fluorescence staining was not observed on the surface of $\mathrm{C} 2 \mathrm{C} 12$ cells incubated with rTsATG4B (Figure 5). Confocal microscopy revealed that $\mathrm{rTs}$ ATG4B could localize to the membrane and cytoplasm of IECs (Figure 6A). Analysis of soluble proteins from IECs and $\mathrm{C} 2 \mathrm{C} 12$ cells by SDSPAGE showed approximately 20-30 bands from 14 to $100 \mathrm{kDa}$ (Additional file 3). The Far-Western blot results of IEC lysates pre-incubated with rTsATG4B showed that there were approximately 10 bands $(20-70 \mathrm{kDa})$ on the membranes probed with anti-rTsATG4B serum and 


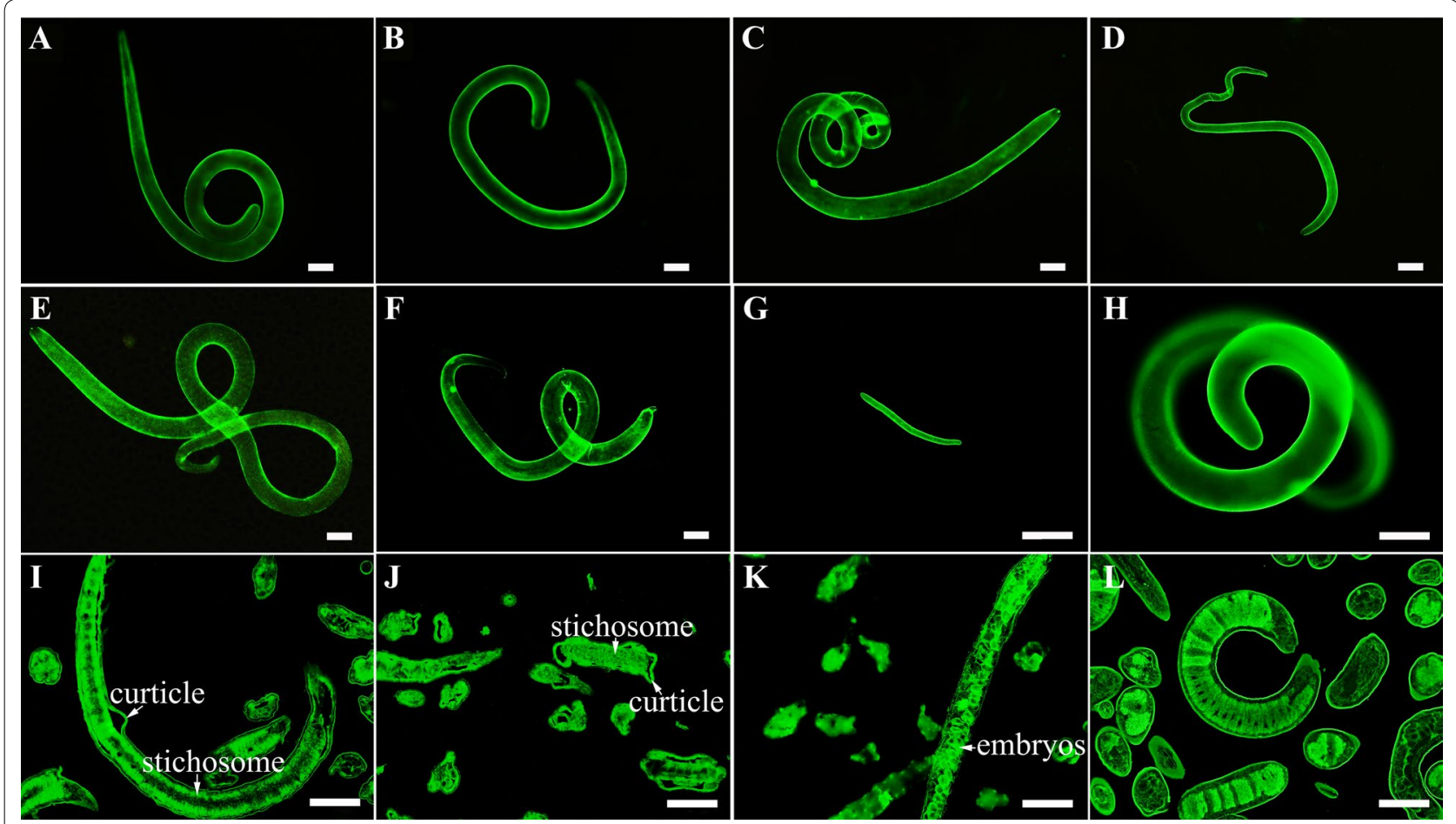

Figure 4 Identification and expression of TsATG4B in the various developmental stages by immunolocalization. A-H Intact worms were recognized by anti-rTsATG 4 B mouse serum, as shown by IFA. Bright immunostaining was displayed on the surface of $M L A$, IIL B, 3 days female AW C, 3 days male AW D, 6 days female AW E, 6 days male AW $\mathbf{F}$, and NBL $\mathbf{G}$. ML $\mathbf{H}$ were probed with infection serum as a positive control. $\mathbf{i}-\mathbf{I}$ Paraffin sections of Trichinella spiralis were recognized by anti-rTsATG4B mouse serum, as shown by IFA. Bright immunostaining was displayed on the cuticles and stichosomes of ML $\mathbf{I}$ and IIL $\mathbf{J}$ and in the embryos of 3 days female AW K. Paraffin sections of Trichinella spiralis ML $\mathbf{L}$ probed with infection serum were used as a positive control. Scale bars: $50 \mu \mathrm{m}$.

infection serum but not with normal serum. C2C12 cell lysates pre-incubated with rTsATG4B were not recognized by anti-TsATG4B serum, infection serum or normal serum (Figure 6B).

\section{Promotive or inhibitory effects of TsATG4B or anti-rTsATG4B serum on larval invasion of IEC monolayers in vitro}

One hundred IIL of each treatment group were cultured in different semi-solid media in $5 \% \mathrm{CO}_{2}$ at $37{ }^{\circ} \mathrm{C}$ for $2 \mathrm{~h}$. Larval invasion was observed under a microscope (Olympus, Japan). Larvae that invaded or migrated in the IEC monolayer, forming trails, leaving dead cells behind and destroying the IEC monolayer, were counted as invaded larvae (Figure 7A). Larvae suspended in the medium or remaining coiled on the cell monolayer surface, not damaging the cells, were defined as uninvaded larvae (Figure 7B). $\mathrm{C} 2 \mathrm{C} 12$ cells were not susceptible to larval invasion [38]; non-invaded larva were observed on the $\mathrm{C} 2 \mathrm{C} 12$ monolayer (Figure $7 \mathrm{C}$ ) as the control for larval invasion of the IEC monolayer.

The results revealed that increasing amounts of rTsATG4B significantly accelerated the invasion of worms into the monolayer (Figure 8A). The acceleration effect had a dose-dependent relationship with rTsATG4B $(\mathrm{r}=0.97, P<0.01)$, and the amount of invasion displayed an increasing trend as the rTsATG4B dose increased $(\mathrm{F}=52.623, P<0.01)$ (Figure $8 \mathrm{~B})$. On the other hand, the acceleration effect was diminished when rTsATG4B was pre-incubated with the same dose of E-64 at $37{ }^{\circ} \mathrm{C}$ for $30 \mathrm{~min}$ before replenishment of the medium (Figure $8 \mathrm{C}$ ). In contrast, anti-rTsATG4B serum and infection serum inhibited larval invasion of IECs $\left(\chi^{2}=112.418\right.$, $P<0.01)$ compared with that in the normal serum group. The inhibitory effect of anti-rTsATG4B serum showed a decreasing trend along with an increase in the dilution; thus, invasion also demonstrated a dose-dependent relationship with anti-rTsATG4B serum $(\mathrm{r}=0.96, P<0.01)$ (Figure 8D). The data are expressed as the standardized suppression rate (\%) relative to the PBS group.

\section{Discussion}

Research has revealed that cysteine proteases are vital contributors to the invasion and migration of host tissues by parasitic organisms, which has attracted scientists' attention. Cysteine proteases degrade host tissues 


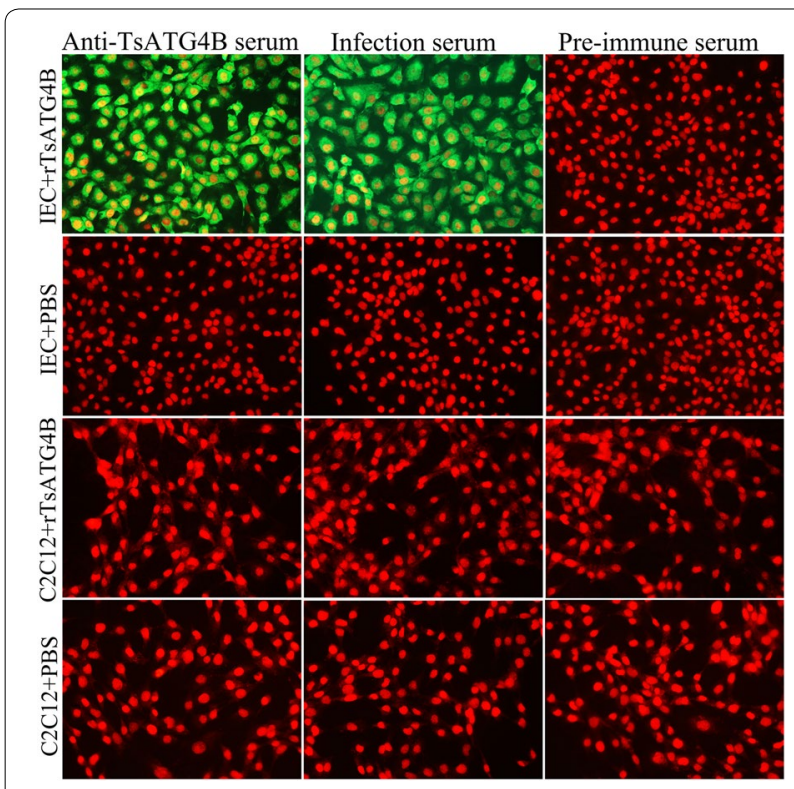

Figure 5 Immunofluorescence assay of rTsATG4B binding to IECs (200x). IECs and C2C12 cells were pre-incubated with rTsATG4B at $37^{\circ} \mathrm{C}$ for $2 \mathrm{~h}$. Then, they were probed with different antibodies (anti-TsATG4B polyclonal antibody, T. spiralis-infected mouse serum and pre-immune mouse serum) and the FITC-conjugated goat anti-mouse lgG secondary antibody and were then counterstained with propidium iodide ( $\mathrm{Pl}$; the fluorescent dye $\mathrm{PI}$ is a nuclear staining reagent that can stain the nucleus through the disrupted cell membrane and emits red fluorescence after embedding in double-stranded DNA). and promote penetration and migration throughout various parasite developmental stages. They also have critical roles in pathogenesis, as they are involved in nutrition, moulting, metabolism and immune modulation [12, 34]. In Trichuris, Drake et al. [35] first used a fluorogenic peptidyl substrate to investigate the activity of a cysteine protease in soluble extracts of Trichuris muris (T. muris) AW in nutrition and invasion. Hasnain et al. [39] revealed that proteolytic activity in T. muris ESPs was necessary for degrading host intestinal tissues. However, this group also indicated that cysteine proteases exist in ESPs and disrupt the network of polymeric mucin. Based on these preliminary studies, this project was instigated to study the role played by TsATG4B in larval invasion of the intestine of the host, and we found promising results in invasion assays.

Cysteine peptidases hydrolyse peptide bonds in a polypeptide chain via a mechanism in which the sulfhydryl group of a cysteine residue at the active centre acts as a nucleophile. Cysteine peptidases can be divided into 14 different clans, and each clan has a tertiary fold unique to that clan. Cysteine peptidases are generally active in acidic environments, such as animal lysosomes or plant vacuoles, which limits their applications. A cysteine peptidase may be an endopeptidase, an aminopeptidase, a carboxypeptidase, a dipeptidyl peptidase or an $\omega$-peptidase. Their bioactivities are inhibited by thiol chelating agents such as iodoacetate, iodoacetic acid, and N-ethylmaleimide $[40,41]$. We investigated whether TsATG4B is recognized by early $T$. spiralis infection sera and ascertained the biochemical characteristics and

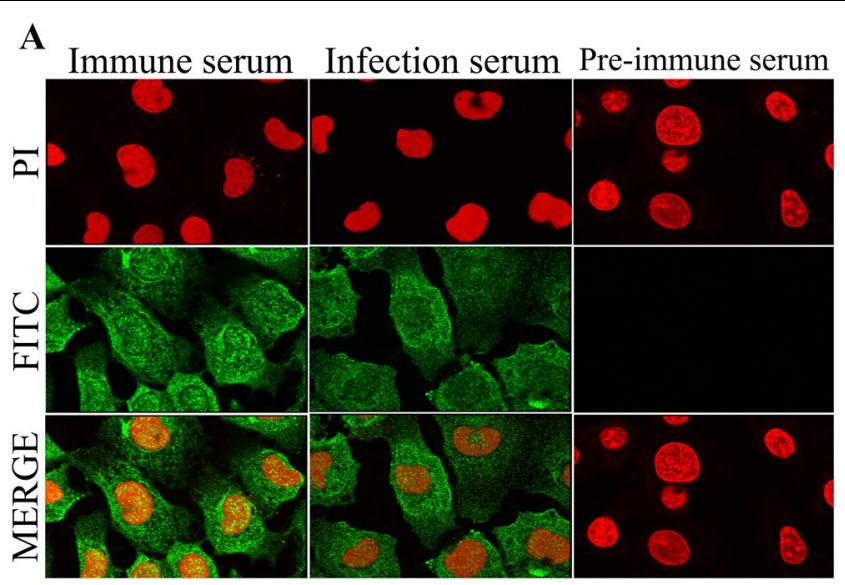

B

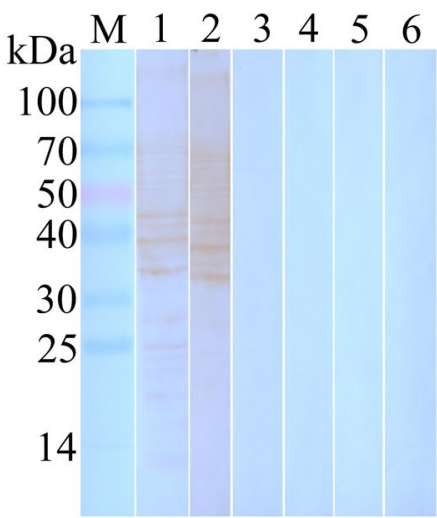

Figure 6 Interaction of TsATG4B with IECs by confocal microscopy and Far-Western blot analysis. A The subcellular localization of rTsATG4B bound to IECs was observed via confocal microscopy (1000x). IECs were pre-incubated with rTsATG4B for $2 \mathrm{~h}$ at $37^{\circ} \mathrm{C}$, and then the same procedure used in the immunofluorescence assay was performed. Images were acquired and analysed with an Olympus FV1200 laser scanning microscope. B Analysis of rTsATG4B binding to IEC proteins by Far-Western blotting. After the IEC lysates (lanes 1-3) and C2C12 lysates (lanes 4-6) were transferred to NC membranes, the NC membranes were incubated with rTsATG $4 \mathrm{~B}$ for $2 \mathrm{~h}$ at $37^{\circ} \mathrm{C}$. Then, the membranes were individually probed with anti-TSATG4B serum (lanes 1, 4), infection serum (lanes 2, 5) and pre-immune serum (lanes 3, 6). Binding between rTSATG4B and IEC lysates was detected with anti-TsATG4B serum (lane 1) and infection serum (lane 2). 

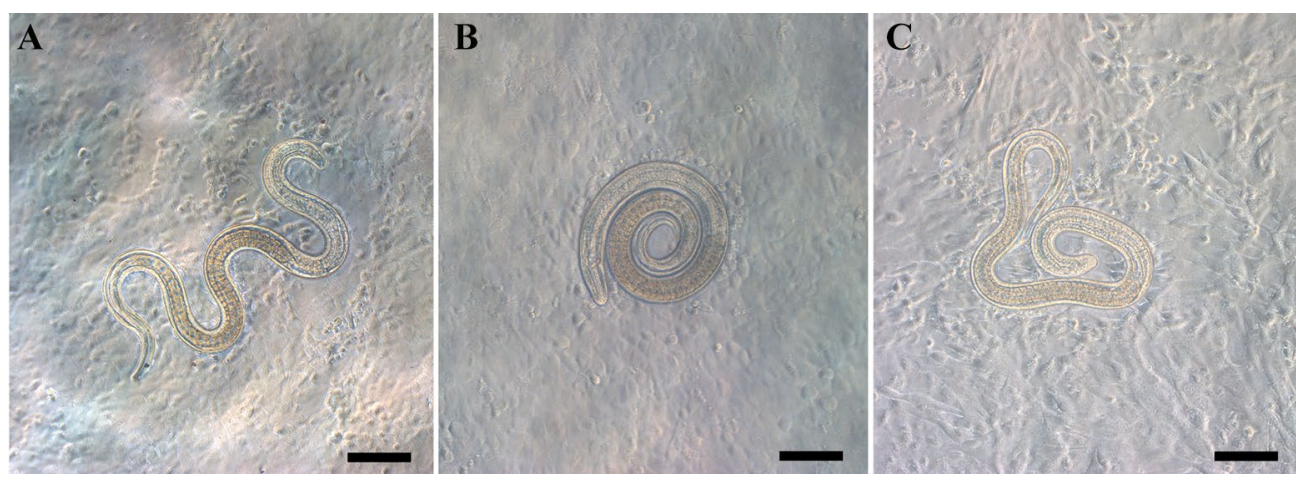

Figure 7 The process of IIL invasion into the intestinal epithelium in vitro. A T. spiralis IIL were shown to invade the epithelial cell monolayer. Larvae penetrated IEC cells and migrated through them, leaving behind trails of dead cells and damaging the IEC monolayer. B Non-invaded larvae on the IEC monolayer. Nematodes that stayed coiled on the surface of the IEC monolayer or suspended in the medium were counted as non-invaded larvae. The IEC monolayer was intact. C Non-invaded larvae on the C2C12 cell monolayer. The larvae on the C2C12 monolayer were coiled. The C2C12 cell monolayer was not damaged. Scale bars: $100 \mu \mathrm{m}$.
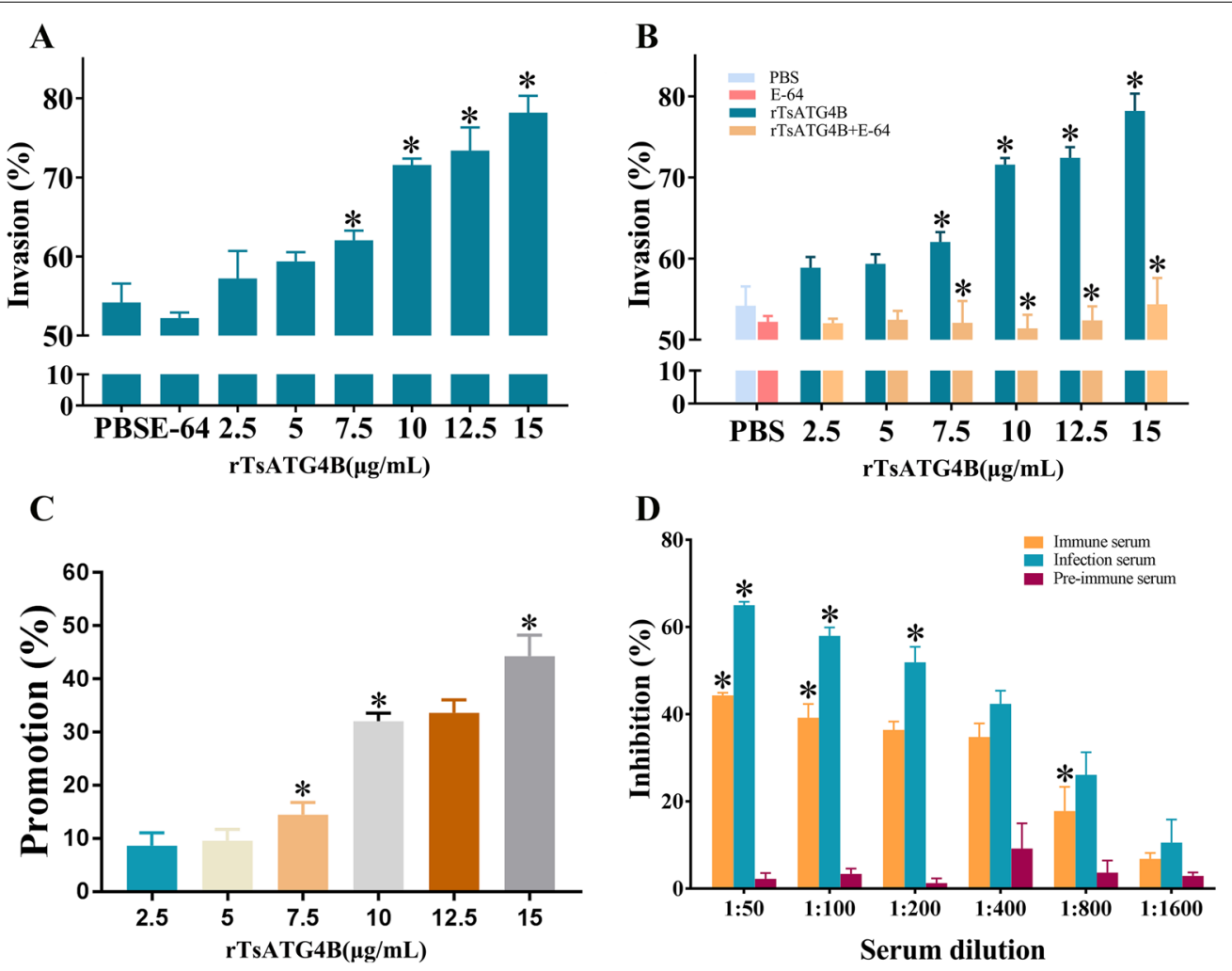

Figure 8 Promotive effect of rTsATG4B protein and inhibitory effect of anti-rTsATG4B serum on larval invasion of the IEC monolayer in vitro. A Promotive effect of rTsATG4B on larval invasion. B The promotive effect on larval invasion was diminished when rTsATG4B was pre-incubated with E-64 (10 $\mu \mathrm{M}, 1: 1)$; c The promotion rate of rTsATG4B protein on T. spiralis larval invasion of the IEC monolayer in vitro. Data were compared with the PBS group as the control. D The inhibition rate of anti-rTsATG4B serum showed a decreasing trend with increasing dilution and displayed a dose-dependent relationship with anti-rTsATG4B serum Data were compared with the PBS group as the control. * $P<0.01$.

functions of TsATG4B during invasion of the host intestine [26]. Only the first 17 amino acid residues, which were predicted to be a non-signal sequence, were deleted, and the rTsATG4B protein was expressed in Escherichia coli. We speculated that a signal peptide exists in TsATG4B, although it was not predicted by SignalP4.1 
Server. The molecular weight of the rTsATG4B protein was approximately $43 \mathrm{kDa}$, consistent with the calculated size.

TsATG4B belongs to the C54 peptidase family (Aut2 peptidase family, clan CA). Clan CA includes proteins with papain-like folds. There is a catalytic triad that occurs in the following order: Cys/His/Asn (or Asp). The fourth residue, usually Gln, is important for stabilizing the acyl intermediate formation during the catalytic process and is upstream of the Cys active site. Folding forms 2 subdomains separated by active sites. Peptidases in clan CA are generally sensitive to small molecule E-64 inhibitors, while E-64 inhibitors are ineffective against other cysteine peptidase families [25, 42]. In our studies, we successfully refolded rTsATG4B. The 1-D zymography results showed that rTsATG4B exhibits gelatinolytic activity at $\mathrm{pH} 5.2$ and that this activity was eliminated by the cysteine protease inhibitor E-64. This gelatinolytic activity may be related to digestion of the host tissue during invasion, migration and pathogenesis [43-47]. More interestingly, another $T$. spiralis cysteine peptidase was investigated as a putative cathepsin F-like protease (TsCF1) by Qu et al. [23]. In their studies, they demonstrated with a Z-Phe-Arg-AMC substrate that rTsCF1 has enzymatic activity after renaturation and that this activity was inhibited by the cysteine protease inhibitor E-64. This study provides valuable references for us to further study the enzymatic activity of TsATG4B. This result prompted us to believe that using fluorescent peptides as substrates to study the activity of proteases is worth investigating and that it is crucial to determine the optimal $\mathrm{pH}$, kinetic parameters and so on.

The qPCR analysis results showed that the level of transcription in 6 days AW was significantly greater than that in the other stages. The Western blot results showed that the rTsATG4B protein was recognized by anti-rTsATG4B serum and infection serum for 20-30 days. Somatic proteins of NBL, ML, IIL, 3 days AW, and 6 days AW and ES proteins of ML were probed with anti-TsATG4B serum for the TsATG4B protein. The IFT results also indicated the expression of TsATG4B at different stages. The results showed that immunostaining was detected on the surfaces, cuticles, and stichosomes and in worm embryos and revealed that TsATG4B was expressed at the levels of transcription and translation throughout all developmental stages of T. spiralis. In our work, native TsATG4B was detected in somatic proteins and ES proteins of ML by Western blotting, indicating that TsATG4B is a somatic protein component of the parasite and likely to be a secreted protein. Additionally, previous studies showed that nudix hydrolase, glutathione $\mathrm{S}$-transferase, serine proteases and aminopeptidase are expressed in various stages of $T$. spiralis development [31, 48, 49]. In other parasites, notably Fasciola hepatica and Schistosoma [50, 51], the expression of various types of cysteine proteases in different developmental stages has been detected, suggesting that these cysteine proteases may have specific functions in each stage, such as the disrupting different tissue barriers or contrasting protein composition. Therefore, we gained insight into the interaction between proteases and barrier cells. In fact, our observations via IFA and confocal microscopy demonstrated the binding and cellular localization of TsATG4B in IECs occurred at the membrane and in the cytoplasm of IECs. The FarWestern blot results showed that approximately 10 bands from IEC lysates pre-incubated with rTsATG4B were recognized by anti-rTsATG4B serum and infectious serum but not by normal serum. This result further confirmed the interactions between TsATG4B and barrier cells. Only these interactions illustrated the important role of TsATG4B in the processes of T. spiralis invasion, colonization, parasite escape, and so on.

The in vitro invasion assay results indicated that the inhibitory effect of anti-rTsATG4B serum was reduced with reducing serum concentration (increasing dilution). Infectious serum and anti-rTsATG4B serum significantly inhibited larval invasion of IECs. Studies have shown that some immune sera against recombinant Trichinella proteins effectively protect the intestinal epithelium against larval invasion $[49,52,53]$. The inhibition mechanism of the antibody against recombinant Trichinella protein could be related to the formation of immune complexes at the end of the larval cephalic stage, which was able to prevent larval invasion [54]. When rTsATG4B was added to the medium, there was an obvious promotion of worm invasion of the IEC monolayer. This promotive effect displayed an increasing trend and a dose-dependent relationship with rTsATG4B. Moreover, the promotive effect of rTsATG4B on larval invasion was diminished when rTsATG4B was pre-incubated with E-64. The excystation of trophozoites of Giardia lamblia and metacercariae of Paragonimus westermani is inhibited or blocked by E-64 in a dose-dependent manner, suggesting that cysteine proteases of these parasites are involved in excystment [55]. Our results also demonstrated that rTsATG4B plays an important role in larval invasion, which may be due to its hydrolytic activity on the host's intestinal epithelium. Since this hydrolysis process can be suppressed by E-64, the TsATG4B protein appears to be an important therapeutic target for trichinellosis.

Our results showed that the transcription and expression of TsATG4B was maintained through all stages of T. spiralis development. TsATG4B was mainly localized on the surfaces, cuticles and stichosomes of the nematode. Refolded rTsATG4B displayed enzymatic activity, which was eliminated by E-64. These findings 
showed the interaction with enterocytes of the host and verified the promotive effect on larval invasion of IECs, which was inhibited by E-64. The anti-rTsATG4B antibody inhibited larval invasion of the IEC monolayer in a dose-dependent manner, which suggested that TsATG4B plays an important role in larval invasion of the intestinal epithelium.

\section{Supplementary information}

Supplementary information accompanies this paper at https://doi. org/10.1186/s13567-020-00791-z.

Additional file 1. Analysis of the amplicons of the TsATG4B gene and T. spiralis $18 \mathrm{~S}$ rRNA gene by $\mathbf{5} \%$ agarose gel electrophoresis. A The amplicon of the TSATG4B gene by agarose gel electrophoresis (76 bp). M: DL 500 DNA marker; 1: ML; 2: IIL; 3: 3 d AW: 4: 6 d AW; 5: NBL; B The amplicon of the T. spiralis $18 \mathrm{~S} r R N A$ gene by agarose gel electrophoresis (117 bp). M: DL 500 DNA marker; 1: ML; 2: IIL; 3: 3 d AW; 4: 6 d AW; 5: NBL.

Additional file 2. Negative control for the TsATG4B immunolocalization assay. The immunolocalization of TsATG4B in intact $M L(\mathbf{A}, \mathbf{B})$. Paraffin sections (C, D) incubated with normal mouse serum $(\mathbf{A}, \mathbf{C})$ and PBS (B, D) served as the negative controls. Scale bars: $50 \mu \mathrm{m}$.

Additional file 3. Analysis of IEC lysates and C2C12 lysates by SDS

PAGE. Lane M: protein molecular weight marker; lane 1: IEC lysates; lane 2 : C2C12 lysates.

\section{Abbreviations}

AW: adult worms; 3 d AW: 3-day-old adult worms; 6 d AW: 6-day-old adult worms; DAB: 3, 3'-diaminobenzidine tetrahydrochloride; EDTA: ethylenediaminetetraacetic acid; ES: excretory-secretory; HRP: horseradish peroxidase; IEC: intestinal epithelial cell; IFA: immunofluorescence assay; IFT: immunofluorescence test; IIL: intestinal infective larvae; IPTG: isopropyl $\beta$-D-1thiogalactopyranoside; ML: muscle larvae; NBL: newborn larvae; ORF: open reading frame; PI: propidium iodide; T. muris: Trichuris muris; TSATG4B: Trichinella spiralis cysteine protease ATG4B; T. spiralis: Trichinella spiralis; rTsATG4B: rsecombinant Trichinella spiralis cysteine protease ATG4B.

\section{Acknowledgements}

We would like to express our sincere thanks to Dr Tiepeng Li, Dr Fang Zhang and Dr Wei Zhang for their technical assistance. We are grateful to Associate Professor Guanyu Chen and Dr Ran Zhao for their revision of the paper. This work was partly supported by the Scientific Research Experimental Center, School of Basic Medical Sciences, Henan University of Chinese Medicine. We confirm that there are no conflicts of interest that will influence this publication

\section{Authors' contributions}

ZQW designed this study. YLL, BYW, YXZ, ZHT, ZY and JQD performed the experiments. YLL analysed the data with the assistance of BYW and JQD. YLL wrote the manuscript. All authors read and approved the final manuscript.

\section{Funding}

This work was mainly supported by the Key Scientific Research Project of Colleges and Universities in Henan Province (2014-J-129-R05/08).

\section{Ethics approval and consent to participate}

Animal experiments in this study were approved by the Life Science Ethics Committee, Henan Province (No. DWLL 201903062).

\section{Competing interests}

The authors declare that they have no competing interests.

\section{Author details}

${ }^{1}$ Department of Pathogen Biology, School of Basic Medical Sciences, Zhengzhou University, Zhengzhou, China. ${ }^{2}$ Scientific Research Experimental Center,
School of Basic Medical Sciences, Henan University of Chinese Medicine, Zhengzhou, China.

Received: 8 December 2019 Accepted: 14 April 2020

Published online: 24 May 2020

\section{References}

1. Murrell KD (2016) The dynamics of Trichinella spiralis epidemiology: out to pasture? Vet Parasitol 231:92-96

2. Cui J, Wang Z, Xu B (2011) The epidemiology of human trichinellosis in China during 2004-2009. Acta Trop 118:1-5

3. Rostami A, Gamble HR, Dupouy-Camet J, Khazan H, Bruschi F (2017) Meat sources of infection for outbreaks of human trichinellosis. Food Microbiol 64:65-71

4. Jiang $P$, Zhang $X$, Wang LA, Han LH, Yang M, Duan JY, Sun GG, Qi X, Liu RD, Wang ZQ (2016) Survey of Trichinella infection from domestic pigs in the historical endemic areas of Henan province, central China. Parasitol Res 115:4707-4709

5. Sequeira GJ, Zbrun MV, Soto LP, Astesana DM, Blajman JE, Rosmini MR, Frizzo LS, Signorini M (2016) Quantitative risk assessment of human trichinellosis caused by consumption of pork meat sausages in Argentina. Zoonoses Public Health 63:167-176

6. Gagliardo L, McVay C, Appleton J (2002) Molting, ecdysis, and reproduction of Trichinella spiralis are supported in vitro by intestinal epithelial cells. Infect Immun 70:1853-1859

7. Wang L, Wang Z, Cui J (2013) Protein changes in Trichinella spiralis muscle larvae in vitro induced by bovine bile. Vet Parasitol 194:164-167

8. Wright K (1979) Trichinella spiralis: an intracellular parasite in the intestinal phase. J Parasitol 65:441-445

9. Ahmad S, Irons BM, Zienkiewicz O (1970) Analysis of thick and thin shell structures by curved finite elements. Int J Numer Meth Eng 2:419-451

10. Cui J, Liu RD, Wang L, Zhang X, Jiang P, Liu MY, Wang ZQ (2013) Proteomic analysis of surface proteins of Trichinella spiralis muscle larvae by twodimensional gel electrophoresis and mass spectrometry. Parasit Vectors 6:355

11. Wang ZQ, Wang L, Cui J (2012) Proteomic analysis of Trichinella spiralis proteins in intestinal epithelial cells after culture with their larvae by shotgun LC-MS/MS approach. J Proteomics 75:2375-2383

12. Grote A, Caffrey CR, Rebello KM, Smith D, Dalton JP, Lustigman S (2018) Cysteine proteases during larval migration and development of helminths in their final host. PLoS Negl Trop Dis 12:e0005919

13. Caffrey CR, Goupil L, Rebello KM, Dalton JP, Smith D (2018) Cysteine proteases as digestive enzymes in parasitic helminths. PLoS Negl Trop Dis 12:e0005840

14. Timms A, Bueding E (1959) Studies of a proteolytic enzyme from Schistosoma mansoni. Br J Pharmacol Chemother 14:68-73

15. Kasný M, Mikes L, Hampl V, Dvorak J, Caffrey CR, Dalton JP, Horak P (2009) Peptidases of trematodes. Adv Parasitol 69:205-297

16. Dalton JP, Brindley PJ, Donnelly S, Robinson MW (2009) The enigmatic asparaginyl endopeptidase of helminth parasites. Trends Parasitol 25:59-61

17. Zocevic A, Mace P, Vallee I, Blaga R, Liu M, Lacour SA, Boireau P (2011) Identification of Trichinella spiralis early antigens at the pre-adult and adult stages. Parasitology 138:463-471

18. Cvetkovic J, Sofronic-Milosavljevic L, Ilic N, Gnjatovic M, Nagano I, Gruden-Movsesijan A (2016) Immunomodulatory potential of particular Trichinella spiralis muscle larvae excretory-secretory components. Int J Parasitol 46:833-842

19. Nagano I, Wu Z, Takahashi Y (2009) Functional genes and proteins of Trichinella spp. Parasitol Res 104:197-207

20. Lee SH, Kim SS, Lee DH, Kim AR, Quan FS (2016) Evaluation of protective efficacy induced by virus-like particles containing a Trichinella spiralis excretory-secretory (ES) protein in mice. Parasit Vectors 9:384

21. Quan FS, Matsumoto T, Lee JB, Timothy O, Lee JS, Kim TS, Joo KH, Lee JS (2004) Immunization with Trichinella spiralis Korean isolate larval excretory-secretory antigen induces protection and lymphocyte subset changes in rats. Immunol Invest 33:15-26 
22. Yépez-Mulia L, Hernández-Bello R, Arizmendi-Puga N, Fonseca-Liñán R, Ortega-Pierres G (2007) Contributions to the study of Trichinella spiralis TSL-1 antigens in host immunity. Parasite Immunol 29:661-670

23. Qu ZG, Ma XT, Li WH, Zhang NZ, Yue L, Cui JM, Cai JP, Jia WZ, Fu BQ (2015) Molecular characterization of a cathepsin F-like protease in Trichinella spiralis. Parasit Vectors 8:652

24. Song YY, Wang LA, Ren HN, Qi X, Sun GG, Liu RD, Jiang P, Zhang X, Cui J, Wang ZQ (2018) Cloning, expression and characterisation of a cysteine protease from Trichinella spiralis. Folia Parasitol 65:2018.007

25. Barrett AJ, Rawlings ND (2001) Evolutionary lines of cysteine peptidases Biol Chem 382:727-734

26. Yang J, Pan W, Sun X, Zhao X, Yuan G, Sun Q, Huang J, Zhu X (2015) Immunoproteomic profile of Trichinella spiralis adult worm proteins recognized by early infection sera. Parasit Vectors 8:20

27. Wang ZQ, Li LZ, Jiang P, Liu LN, Cui J (2012) Molecular identification and phylogenetic analysis of Trichinella isolates from different provinces in mainland China. Parasitol Res 110:753-757

28. Gamble H, Bessonov A, Cuperlovic K, Gajadhar A, Van Knapen F, Noeckler K, Schenone H, Zhu X (2000) International Commission on Trichinellosis: recommendations on methods for the control of Trichinella in domestic and wild animals intended for human consumption. Vet Parasitol 93:393-408

29. Ren HJ, Cui J, Wang ZQ, Liu RD (2011) Normal mouse intestinal epithelial cells as a model for the in vitro invasion of Trichinella spiralis infective larvae. PLoS One 6:e27010

30. Todorova V, Knox D, Kennedy M (1995) Proteinases in the excretory/secretory products (ES) of adult Trichinella spiralis. Parasitology 111:201-208

31. Long SR, Wang ZQ, Jiang P, Liu RD, Qi X, Liu P, Ren HJ, Shi HN, Cui J (2015) Characterization and functional analysis of Trichinella spiralis Nudix hydrolase. Exp Parasitol 159:264-273

32. Jevševar S, Gaberc-Porekar V, Fonda I, Podobnik B, Grdadolnik J, Menart V (2005) Production of nonclassical inclusion bodies from which correctly folded protein can be extracted. Biotechnol Prog 21:632-639

33. Yang Z, Li W, Yang Z, Pan A, Liao W, Zhou X (2018) A novel antigenic cathepsin B protease induces protective immunity in Trichinella-infected mice. Vaccine 36:248-255

34. McKerrow JH, Caffrey C, Kelly B, Loke PN, Sajid M (2006) Proteases in parasitic diseases. Annu Rev Pathol 1:497-536

35. Drake L, Bianco A, Bundy D, Ashall F (1994) Characterization of peptidases of adult Trichuris muris. Parasitology 109:623-630

36. Liu LN, Wang ZQ, Zhang X, Jiang P, Qi X, Liu RD, Zhang ZF, Cui J (2015) Characterization of Spirometra erinaceieuropaei plerocercoid cysteine protease and potential application for serodiagnosis of sparganosis. PLoS Negl Trop Dis 9:e0003807

37. Schmittgen TD, Livak KJ (2008) Analyzing real-time PCR data by the comparative C T method. Nat Protoc 3:1101-1108

38. ManWarren T, Gagliardo L, Geyer J, McVay C, Pearce-Kelling S, Appleton J (1997) Invasion of intestinal epithelia in vitro by the parasitic nematode Trichinella spiralis. Infect Immun 65:4806-4812

39. Hasnain SZ, McGuckin MA, Grencis RK, Thornton DJ (2012) Serine protease(s) secreted by the nematode Trichuris muris degrade the mucus barrier. PLoS Negl Trop Dis 6:e1856

40. Rajković J, Poreba M, Caglič D, Vidmar R, Wilk A, Borowik A, Salvesen G, Turk V, Drag M, Turk B (2015) Biochemical characterization and substrate specificity of autophagin-2 from the parasite Trypanosoma cruzi. J Biol Chem 290:28231-28244

41. Ortega-Pierres G, Argüello-García R, Laredo-Cisneros MS, Fonseca-Linán R, Gómez-Mondragón M, Inzunza-Arroyo R, Flores-Benítez D, Raya-Sandino
A, Chavez-Munguía B, Ventura-Gallegos JL (2018) Giardipain-1, a protease secreted by Giardia duodenalis trophozoites, causes junctional, barrier and apoptotic damage in epithelial cell monolayers. Int J Parasitol 48:621-639

42. Liu LN, Zhang X, Jiang P, Liu RD, Zhou J, He RZ, Cui J, Wang ZQ (2015) Serodiagnosis of sparganosis by ELISA using recombinant cysteine protease of Spirometra erinaceieuropaei spargana. Parasitol Res 114:753-757

43. Barrett AJ, Kembhavi A, Brown M, Kirschke H, Knight C, Tamai M, Hanada K (1982) L-trans-Epoxysuccinyl-leucylamido (4-guanidino) butane (E-64) and its analogues as inhibitors of cysteine proteinases including cathepsins B, H and L. Biochem J 201:189-198

44. Chen J-M, Rawlings ND, Stevens RA, Barrett AJ (1998) Identification of the active site of legumain links it to caspases, clostripain and gingipains in a new clan of cysteine endopeptidases. FEBS Lett 441:361-365

45. Zong Y, Mazmanian SK, Schneewind O, Narayana SV (2004) The structure of sortase $B$, a cysteine transpeptidase that tethers surface protein to the Staphylococcus aureus cell wall. Structure 12:105-112

46. Song CY, Chappell CL (1993) Purification and partial characterization of cysteine proteinase from Spirometra mansoni plerocercoids. J Parasitol 79:517-524

47. Kong Y, Chung Y-B, Cho S-Y, Kang S-Y (1994) Cleavage of immunoglobulin $\mathrm{G}$ by excretory-secretory cathepsin S-like protease of Spirometra mansoni plerocercoid. Parasitology 109:611-621

48. Zhang Y, Wang Z, Li L, Cui J (2013) Molecular characterization of Trichinella spiralis aminopeptidase and its potential as a novel vaccine candidate antigen against trichinellosis in BALB/C mice. Parasit Vectors 6:246

49. Wang B, Wang ZQ, Jin J, Ren HJ, Liu LN, Cui J (2013) Cloning, expression and characterization of a Trichinella spiralis serine protease gene encoding a 35.5 kDa protein. Exp Parasitol 134:148-154

50. Wilson LR, Good RT, Panaccio M, Wijffels GL, Sandeman RM, Spithill TW (1998) Fasciola hepatica: characterization and cloning of the major cathepsin B protease secreted by newly excysted juvenile liver fluke. Exp Parasitol 88:85-94

51. McKerrow J, Doenhoff M (1988) Schistosome proteases. Parasitol Today 4:334-340

52. Cui J, Li LG, Jiang P, Liu RD, Yang X, Liu LN, Liu P, Zhang SB, Wang ZQ (2015) Biochemical and functional characterization of the glutathione S-transferase from Trichinella spiralis. Parasitol Res 114:2007-2013

53. Liu CY, Ren HN, Song YY, Sun GG, Liu RD, Jiang P, Long SR, Zhang X, Wang ZQ, Cui J (2018) Characterization of a putative glutathione S-transferase of the parasitic nematode Trichinella spiralis. Exp Parasitol 187:59-66

54. McVay CS, Bracken P, Gagliardo LF, Appleton J (2000) Antibodies to tyvelose exhibit multiple modes of interference with the epithelial niche of Trichinella spiralis. Infect Immun 68:1912-1918

55. Chung YB, Kong Y, Joo IJ, Cho SY, Kang SY (1995) Excystment of Paragonimus westermani metacercariae by endogenous cysteine protease. J Parasitol 81:137-142

\section{Publisher's Note}

Springer Nature remains neutral with regard to jurisdictional claims in published maps and institutional affiliations. 